\title{
Annotated type catalogue of land snails collected from Taiwan (Formosa) in the Natural History Museum, London
}

\author{
Chung-Chi Hwang' \\ I Department of Life Sciences, National University of Kaohsiung, No.700, Kaohsiung University Road, Nan- \\ Tzu District, Kaohsiung 81148, Taiwan \\ Corresponding author: Chung-Chi Hwang (cchwang@nuk.edu.tw)
}

Academic editor: Frank Köhler | Received 7 June 2014 | Accepted 15 July 2014 | Published 23 July 2014

http://zoobank.org/F2C3B34B-FOFB-4B59-8808-1F250FD3034B

Citation: Hwang C-C (2014) Annotated type catalogue of land snails collected from Taiwan (Formosa) in the Natural History Museum, London. ZooKeys 428: 1-28. doi: 10.3897/zookeys.428.8061

\begin{abstract}
The present catalogue lists the type specimens of land snail species, collected from Taiwan and deposited in the Natural History Museum, London. Thirty-seven nominal species described by Pfeiffer, Adams, Nevill, Moellendorff, Godwin-Austen and Gude were traced. I present here information on type status, collection data obtained from the registers and labels of each collection, and annotations on the current taxonomic affiliation. Lectotypes of 28 nominal (sub)species were newly designated. One holotype was fixed originally and two holotypes newly fixed by monotypy. Syntypes of two species and paralectotypes of three species were also discovered in the Museum. No specimen of the species Pupina adamsi Sowerby, 1878, which was supposed to be deposited in the NHM, was found. Pictures of the name-bearing types are provided for further research on biodiversity of the island.
\end{abstract}

\section{Keywords}

Type specimen, taxonomy, Taiwan, Gastropoda, land snail

Copyright Chung-Chi Hwang. This is an open access article distributed under the terms of the Creative Commons Attribution License (CC BY 4.0), which permits unrestricted use, distribution, and reproduction in any medium, provided the original author and source are credited. 


\section{Introduction}

Taxonomic research on historic collections is essential for the modern study of taxonomy and biodiversity. Current taxonomic studies using morphological or molecular methods, e.g., Barcode of Life (Hebert et al. 2003), are among the important issues of organismal, as well as ecological and genetic diversity. However, these attempts will not achieve practical results without a correct identification of species. The most common challenge in current studies of land snail biodiversity in Taiwan is that the sampled specimens cannot be identified correctly and confidently, especially within microsnail taxa such as the diplommatinids. Researchers face similar problems concerning large snail groups such as the clausiliids (Hwang 2005). This situation is mainly due to a lack of type specimens for comparisons since most of the historic types are deposited abroad. The oversimplified descriptions and imprecise illustrations in the original publications from the 19th and early 20th centuries are not practical for modern research. Before complete systematic revisions of each group are possible, concise and updated reports on these types are urgently needed for biodiversity studies in Taiwan. Most of the types collected from Taiwan and deposited in the Naturmuseum Senckenberg, Frankfurt am Main have been reported and photographed in a series of publications by Zilch (e.g., 1953, 1966a, 1966b, 1968). Types described in the 1940s and deposited in the Nishinomiya Shell Museum, Japan, have been catalogued and photographed by Habe and Inaba (1996), Ohara and Otani (2002) and Hwang et al. (2008). Determinations of Taiwanese holotypes and lectotypes deposited in the Academy of Natural Sciences of Philadelphia, U.S.A., were accomplished by Baker $(1963,1964)$.

The Natural History Museum of London contains many specimens collected in Taiwan (Formosa). A major portion of these are housed in the type series which were previously in the collection of $\mathrm{H}$. Cuming and H. Adams (Adams 1866; Pfeiffer 1866; Gray 1868). Most of these collections from the island were assembled by R. Swinhoe, a British consul and a pioneer of the study of the natural history in Taiwan (Swinhoe 1864, 1865; Fraser 1865, 1866). Pfeiffer (1866) described 13 species of land snails from Cuming's collection; $\mathrm{H}$. Adams $(1866,1867,1870,1872)$ described 16 species from the collections of the Natural History Museum of London and his own. Some of the types described by other researchers such as Sowerby (1878), Godwin-Austen (1907) and Gude (1907), who worked in or with the NHM, are also deposited in the NHM. These type lots have not been re-examined and catalogued since their original publication. The present report provides the first catalogue and photographs of these type specimens.

\section{Methods}

In preparing this catalogue, type specimens were recognized and verified by comparing information on the specimen labels, the original descriptions, NHM registers and curatorial records of the Mollusca Section, Natural History Museum, London. 
The type specimens are listed using modern classifications (Vaught 1989; Bouchet and Rocroi 2005; Hsieh et al. 2013). The collection data obtained from the registers and labels of each collection is provided. The publication dates of those names described in the Proceedings of the Zoological Society of London are corrected according to Duncan (1937). Taxonomic annotations are made when required. Photographs of the types are provided when they have not previously been presented. Type localities are cited as in original descriptions. The modern locality names in Hanyu Pinyin Romanisation are provided in brackets. Dimensions of shells are given as: shell height $x$ shell width. An updated and detailed description of these type materials will be presented elsewhere in systematic studies of their respective groups.

\section{Institutional abbreviations}

NHM, Natural History Museum, London, U.K. (NHM registered specimens are cited as NHMUK); ANSP, Academy of Natural Sciences of Philadelphia, U.S.A.; SMF, Naturmuseum Senckenberg, Frankfurt am Main, Germany.

\section{Results}

I was able to find type specimens of 37 species in the NHM, including all 13 species identified by Pfeiffer (1866) and all 16 by Adams (1866, 1867, 1870, 1872). These specimens are listed in a current taxonomic assignment of nine families including the Cyclophoridae, Diplommatinidae, Pupinidae, Clausiliidae, Streptaxidae, Trochomorphidae, Ariophantidae, Bradybaenidae and Camaenidae. Specimens of Pupina adamsi Sowerby, 1878, which are supposedly deposited in the NHM, were not found. Types of eight additional species described by Nevill (1881, two species), Moellendorff (1884, one species), Godwin-Austen (1907, two species), Gude (1907, one species) and Rolle (1911, two species) from various collections were found. Lectotypes of 28 species were newly designated. Paralectotypes of three species, the lectotype of each having already been designated, were found. A holotype of one species was fixed by original designation and holotypes of two species have been fixed by monotypy in the present catalogue. Syntypes of two species were discovered, but no lectotypes were designated as more suitable material for lectotype designation may be kept in the museum where the respective author worked.

Specimens from the collections of shell dealers B. Schmacker (Shanghai, China) and Y. Hirase (Kyoto, Japan) were also found. These species were described by Schmacker and Boettger (1891), Pilsbry (1905) and Pilsbry and Hirase (1905-1906, 1909). Boettger and Pilsbry were the major contributors for description and publication. Due to a lack of evidence, e.g. original labels, of proof of examination of these specimens by Boettger and Pilsbry, these materials were excluded from the type series until further evidence can be found. 
I noted the following features in the collection. (1) All specimens are cased in boxes having an originally handwritten label glued onto the bottom. The register information, if any, was also written on the bottoms of the cases. A concise locality, usually "Formosa" only, with or without a collector, was provided. (2) Some specimen lots are labelled "TYPE" using ink and handwriting different from the original labels. Such conditions are supposed to be determined as types and written by a curator or later researchers rather than by the original authors. (3) Ten species described by Adams (1866, 1867, 1870, 1872) were deposited in two batches in the NHM. One batch consists of the specimens that Swinhoe presented to the NHM in 1866, being subsequently examined and named by Adams. The other batch is Adams' own collection purchased by the NHM in 1878 after his death. Since all specimens were examined by Adams, both are considered as being from the type series.

\section{Catalogue}

\section{Family CYCLOPHORIDAE \\ Genus Cyclotus Swainson, 1840}

\section{Cyclotus taivanus $\mathrm{H}$. Adams, 1870}

http://www.taibif.tw/en/catalogue_of_life/page/4e53-43b4-ed74-0962-a6da-f1135fbb-174b-namecode-405332

Figure $1 \mathrm{~A}$

Cyclotus taivanus H. Adams, 1870: 378-379, pl. 27 figs. 11, 11a.

Type locality. Taiwan, Formosa [Taiwan Fu = Tainan City and northern Kaohsiung City] (Swinhoe).

Material examined. Lectotype. Formosa, coll. Swinhoe (NHMUK 1871.1.20.9/1), new designation, $10.1 \times 16.5 \mathrm{~mm}$, whorls 4.5 .

Paralectotypes. Formosa, coll. Swinhoe (NHMUK 1871.1.20.9/2-8, 7 shells). Taiwan, Formosa, from collection of H. Adams (NHMUK 1878.1.28.22, 3 shells).

Remarks. The lot NHMUK 1871.1.20.9 was registered and labelled as "Cyclotus formosensis", but was later published as C. taivanus. Nine specimens were registered, but only eight were found. The specimen corresponding well in size with the measurement of Adams (1870) is designated as the lectotype for the stabilization of the name (ICZN 1999: Art. 74). 


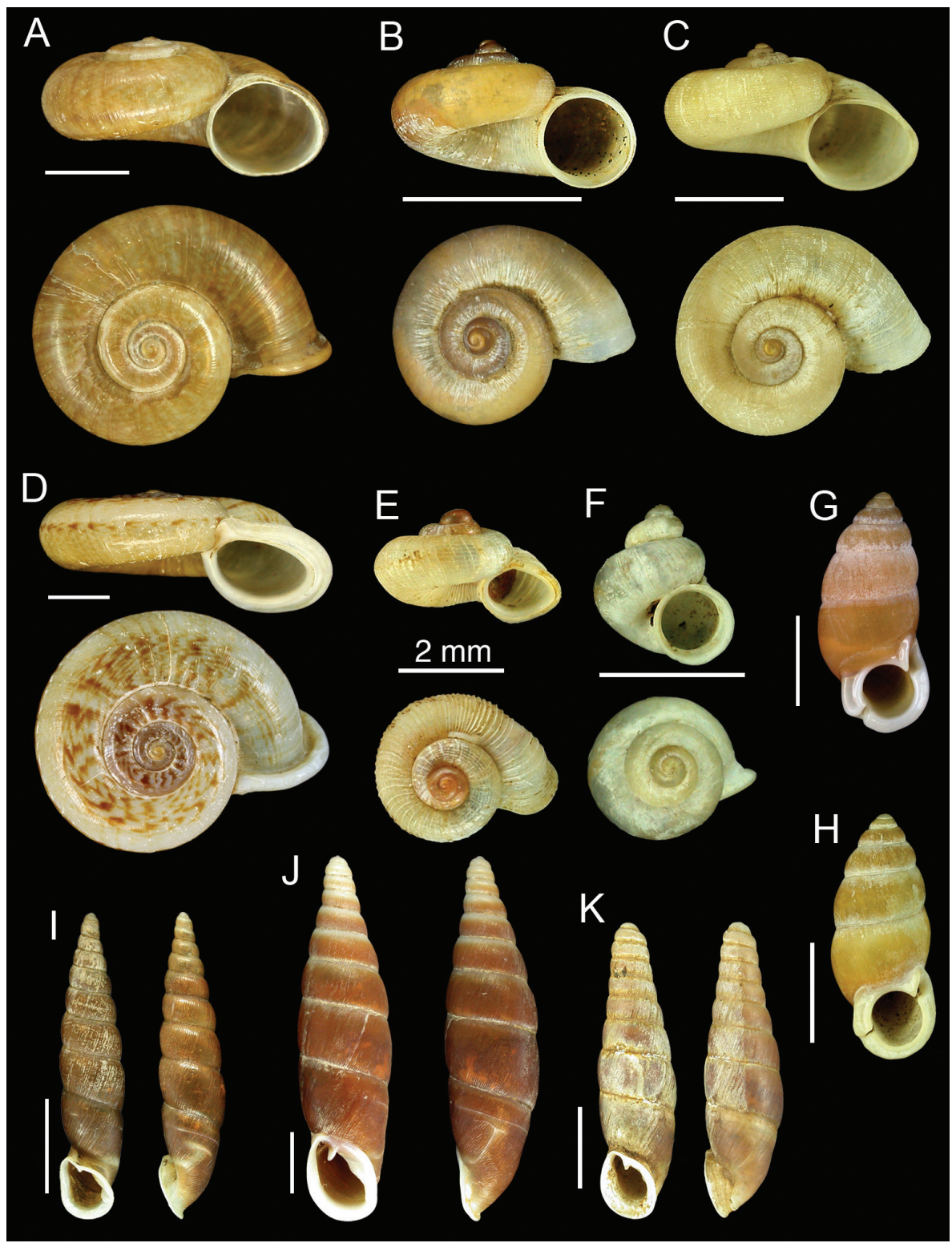

Figure I. A Cyclotus taivanus H. Adams, 1870, lectotype NHMUK 1871.1.20.9/1 B Platyrhaphe minutus (H. Adams, 1866), lectotype NHMUK 1866.5.9.6/1 C Platyrhaphe swinhoei (H. Adams, 1866), lectotype NHMUK 1866.5.9.7/10 D Ptychopoma wilsoni (Pfeiffer, 1866), lectotype NHMUK 20040584/1 E Chamalycaeus hungerfordianus (Nevill, 1881), possible syntype NHMUK 1891.3.17.790 F Dioryx swinhoei (H. Adams, 1866), lectotype NHMUK 1866.5.9.8/1 G Pupinella swinhoei (H. Adams, 1866), lectotype NHMUK 1866.5.9.15/1 H Pupinella swinhoei syn. Pupinopsis morrisonia H. Adams, 1872, lectotype NHMUK 1871.1.20.16/1 I Euphaedusa sheridani (Pfeiffer, 1866), lectotype NHMUK 20040589/1 J Hemiphaedusa exilis (H. Adams, 1866), lectotype NHMUK 1866.5.9.4/1 K Hemiphaedusa similaris (H. Adams, 1867), lectotype NHMUK 1878.1.28.10/1. Scale bars $=5 \mathrm{~mm}$, unless otherwise specified above the bar. 


\section{Genus Platyrhaphe Moellendorff, 1890}

Platyrhaphe minutus (H. Adams, 1866)

http://www.taibif.tw/en/catalogue_of_life/page/1451-61f0-132b-71f5-e030-a36b-75a31ab7-namecode-315206

Figure 1B

Cyclotus minutus H. Adams, 1866: 318, pl. 33 fig. 10.

Platyrhaphe minutus, Kobelt and Moellendorff 1897: 115.

Type locality. Takow, Formosa [northern Qi-Jin, Kaohsiung City] (Swinhoe)

Material examined. Lectotype. Formosa, coll. Swinhoe (NHMUK 1866.5.9.6/1), new designation, $4.4 \times 6.9 \mathrm{~mm}$, whorls 4 .

Paralectotypes. Formosa, coll. Swinhoe (NHMUK 1866.5.9.6/2-3, 2 shells). Formosa, from collection of $\mathrm{H}$. Adams (NHMUK 1878.1.28.73, 3 shells).

Remarks. Adams (1866) described the locality as Takow, Formosa, but the original label has only "Formosa". The specimen corresponding well in size with the measurement of Adams (1866) and having sculptures in good condition is designated as the lectotype for the stabilization of the name (ICZN 1999: Art. 74).

\section{Platyrhaphe swinhoei (H. Adams, 1866)}

http://www.taibif.tw/en/catalogue_of_life/page/4f5b-8cf6-7311-1585-f526-3427-7340e0db-namecode-315208

Figure 1C

Cyclotus swinhoei $\mathrm{H}$. Adams, 1866: 318, pl. 33 fig. 9.

Platyrhaphe swinhoei, Kobelt and Moellendorff 1897: 116.

Type locality. Takow, Formosa [northern Qi-Jin, Kaohsiung City] (Swinhoe)

Material examined. Lectotype. Formosa, coll. Swinhoe (NHMUK 1866.5.9.7/1, new designation, $6.8 \times 11.6 \mathrm{~mm}$, whorls 4.5 .

Paralectotype. Formosa, coll. Swinhoe (NHMUK 1866.5.9.7/2, 1 shell). Formosa, from collection of H. Adams (NHMUK 1878.1.28.231, 1 shells)

Remarks. Adams (1866) described the locality as Takow, Formosa. However, this species was not actually collected there. I think Swinhoe and Adams used Takow to designate the area presently known as Kaohsiung City (Wu et al. 2008; also see remarks for Oospira formosensis (Adams, 1866)). The largest specimen corresponds well in size with the measurements of Adams (1866). It is here selected as the lectotype. 


\section{Genus Ptychopoma Moellendorff, 1885}

\section{Ptychopoma wilsoni (Pfeiffer, 1866)}

http://www.taibif.tw/en/catalogue_of_life/page/a1f3-b693-4cad-94cc-160c-98ae-38b497d0-namecode-405367

Figure 1D

Pterocyclos wilsoni Pfeiffer, 1866: 831, pl. 46 fig. 12. [1865] (Apr. 1866).

Ptychopoma wilsoni, Kobelt and Moellendorff 1897: 88.

Type locality. Formosa [Taiwan] (Swinhoe).

Material examined. Lectotype. Formosa, coll. Swinhoe, from collection of $\mathrm{H}$. Cuming (NHMUK 20040584/1). new designation, $9.4 \times 22.5 \mathrm{~mm}$, whorls 5 .

Paralectotypes. Formosa, coll. Swinhoe, from collection of H. Cuming (NHMUK 20040584/2-3, 2 shells).

Remarks. No specimen corresponds in size with the measurements of Pfeiffer (1866). The largest specimen mostly similar to the illustration in Pfeiffer (1866) is designated as the lectotype.

\section{Genus Chamalycaeus Kobelt \& Moellendorff, 1897}

\section{Chamalycaeus hungerfordianus (Nevill, 1881)}

http://www.taibif.tw/en/catalogue_of_life/page/a6ad-a451-ead1-6549-84d1-38b3-4b28fed5-namecode-315080

Figure $1 \mathrm{E}$

Alycaeus hungerfordianus Nevill, 1881: 149-150.

Chamalycaeus hungerfordianus, Kuroda 1941: 81.

Type locality. Tamsui, Formosa [Danshui, New Taipei City] (Hungerford).

Material examined. Possible syntypes: Tamsui, Formosa, from collection of Hungerford (NHMUK 1891.3.17.790-791, 2 shells), 2.2-2.5 × 3.6-3.8 mm, whorls 3.75. Also in SMF (Zilch 1957).

Remarks. It is possible that further syntypes may be housed in the Indian Museum, Kolkata (Calcutta), India, where Nevill worked. Due to the lack of definitive evidence that the two specimens in the NHM were actually examined by Nevill, no lectotype designation has been made in the present article. 


\section{Genus Dioryx Benson, 1859}

\section{Dioryx swinhoei (H. Adams, 1866)}

http://www.taibif.tw/en/catalogue_of_life/page/e2c6-32a9-1653-e068-3819-bac2-23e33913-namecode-315083

Figure $1 \mathrm{~F}$

Alycaeus (Dioryx) swinhoei H. Adams, 1866: 318, pl. 33 fig. 11.

Dioryx swinhoei, Kobelt and Moellendorff 1897: 149.

Type locality. Takow, Formosa [northern Qi-Jin, Kaohsiung City] (Swinhoe).

Material examined. Lectotype. Formosa, coll. Swinhoe (NHMUK 1866.5.9.8/1), new designation, $6.0 \times 5.5 \mathrm{~mm}$, whorls 4 .

Paralectotype. Formosa, coll. Swinhoe (NHMUK 1866.5.9.8/2, 1 shell).

Remarks. Adams (1866) described the locality as Takow, Formosa, but the original label has only "Formosa". Also see remarks for Oospira formosensis (Adams, 1866). The specimen with intact shell is designated as the lectotype.

\section{Family DIPLOMMATINIDAE}

Genus Diplommatina Benson, 1849

\section{Diplommatina hungerfordiana Nevill, 1881}

http://www.taibif.tw/en/catalogue_of_life/page/ca4a-ac7e-eeb0-ddb1-72a0-a26f0975-efa5-namecode-315295

Diplommatina hungerfordiana Nevill, 1881: 150.

Type locality. Kulung, Formosa [should be Keelung, Northern Taiwan] (Hungerford).

Material examined. Possible syntypes: Formosa, coll. Hungerford (NHMUK 1891.3.17.724-726, 3 shells), 2.76-3.29 × 1.66-1.76 mm, whorls 5.5-6.5. Also in SMF (Zilch 1953, Figure 186).

Remarks. A photograph of a syntype was provided by Zilch (1953). Also see remarks for Chamalycaeus hungerfordianus (Nevill, 1881).

\section{Family PUPINIDAE}

\section{Genus Pupinella Gray, 1850}

\section{Pupinella swinhoei $\mathrm{H}$. Adams, 1866}

http://www.taibif.tw/en/catalogue_of_life/page/4a7f-dfe1-59ea-ba46-f071-e4d17286-f51d-namecode-315419

Figure 1G 
Pupinella (Pupinopsis) swinhoei H. Admas, 1866: 318, pl. 32 figs. 12, 12a.

Type locality. Tamsui, Formosa [Danshui, New Taipei City] (Swinhoe).

Material examined. Lectotype of Pupinella swinhoei. Formosa, coll. Swinhoe (NHMUK 1866.5.9.15/1), new designation, $13 \times 5.5 \mathrm{~mm}$, whorls 7. (Figure 1G).

Paralectotypes of Pupinella swinhoei. Formosa, coll. Swinhoe (NHMUK 1866.5.9.15/2-3, 2 shells). Formosa, from collection of H. Adams (NHMUK 1878.1.28.58, 3 shells)

Remarks. Adams (1866) described the locality of P. swinhoei as Tamsui, Formosa, but the original label has only "Formosa". The largest specimen corresponds well in size with the measurements of Adams (1866). It is here selected as the lectotype for the stabilization of the name (ICZN 1999: Art. 74).

\section{Pupinella swinhoei H. Adams, 1866}

\section{Syn. Pupinopsis morrisonia H. Adams, 1872}

Figure $1 \mathrm{H}$

Pupinopsis morrisonia H. Adams, 1872: 13, pl. 3 fig. 21.

Type locality. Mount Morrison, Formosa [Mt. Yushan] (Swinhoe).

Material examined. Lectotype of Pupinopsis morrisonia. South Formosa, coll. Swinhoe (NHMUK 1871.1.20.16/1), new designation, $12.5 \times 5.3 \mathrm{~mm}$, whorls 6.5. (Figure 1H).

Paralectotypes of Pupinopsis morrisonia. South Formosa, coll. Swinhoe (NHMUK1871.1.20.16/2, 1 shell). Mt. Morrison, South Formosa, from collection of H. Adams (NHMUK 1878.1.28.50, 3 shells).

Remarks. No specimen corresponds in size with the measurements and illustration of Adams (1872). The specimen similar to the measurements and in the best condition is designated as the lectotype.

\section{Pupinella swinboei H. Adams, 1866}

Syn. Pupina adamsi Sowerby, 1878

Pupina adamsi Sowerby, 1878: sp. 33, pl. 4 fig. 33.

Type locality. Isl. Formosa [Taiwan] (ex. Mus. Brit.)

Remarks. The type specimen of $P$. adamsi, which was collected from Formosa and has been stated as being deposited in the NHM (Sowerby 1878), was not found. 


\section{Family CLAUSILIIDAE \\ Genus Euphaedusa Boettger, 1877}

\section{Euphaedusa sheridani (Pfeiffer, 1866)}

http://www.taibif.tw/en/catalogue_of_life/page/c4cf-3a16-c980-f269-6ba0-090e-dccb2c8d-namecode-316614

Figure 1I

Clausilia sheridani Pfeiffer, 1866: 830-831. [1865] (Apr. 1866).

Euphaedusa sheridani, Yen 1939: 107, pl. 10, fig. 54.

Type locality. Formosa [Taiwan] (Swinhoe).

Material examined. Lectotype. Formosa, coll. Swinhoe, from collection of $\mathrm{H}$. Cuming NHMUK 20040589/1), new designation, $16.0 \times 3.5 \mathrm{~mm}$, whorls 10 .

Paralectotypes. Formosa, coll. Swinhoe, from collection of H. Cuming (NHMUK 20040589/2-4, 3 shells; NHMUK 20040589/5, 1 shell, non sheridani).

Remarks. Pfeiffer (1866) described a variety with a projecting peristome inside, a narrowed aperture and an inconspicuous inferior lamella. Among the five specimens found, two shells are typical sheridani and two shells are of variety. The variations observed in the variety are caused by the thickened callus in the aperture of the fully matured shells. The original description gives a range of shell dimensions.

The largest specimen corresponds well in size with the measurements of Pfeiffer (1866). It is here selected as the lectotype for the stabilization of the name (ICZN 1999: Art. 74). The specimen NHMUK 20040589/5 has similar shell dimensions, but it differs from the other four in having a thin and brownish corneous exterior, a shinier surface, finer striation, a less expanded peristome, a non-protruding aperture and a superior lamella not connected to the spiral lamella. This specimen is closely resembles E. aculus (Benson, 1842) allies but is not a true E. sheridani. Because this specimen was examined by Pfeiffer, it should be included in the type series (ICZN 1999: Art. 72.4, 73.2). This specimen is still designated as a paralectotype.

\section{Genus Hemiphaedusa Boettger, 1877}

\section{Hemiphaedusa exilis (H. Adams, 1866)}

http://www.taibif.tw/en/catalogue_of_life/page/4ac5-7dd6-1c05-dee6-b6a0-6f0ea9a7-710b-namecode-316633

Figure 1J

Clausilia (Laciniaria) exilis H. Adams, 1866: 317, pl. 33 fig. 6.

Hemiphaedusa exilis, Kuroda 1941: 140.

Type locality. Tamsui, Formosa [Danshui, New Taipei City] (Swinhoe). 
Material examined. Lectotype. Formosa, coll. Swinhoe (NHMUK 1866.5.9.4/1), new designation, $27.0 \times 7.1 \mathrm{~mm}$, whorls 10 .

Paralectotypes. Formosa, coll. Swinhoe (NHMUK 1866.5.9.4/2-3, 2 shells). Formosa, from collection of H. Adams (NHMUK 1878.1.28.207, 2 shells).

Remarks. Adams (1866) described the locality as Tamsui, Formosa, but the original label has only "Formosa". The specimen corresponding well in size with the measurements of $\mathrm{H}$. Adams (1866) is designated as the lectotype for the stabilization of the name (ICZN 1999: Art. 74).

\section{Hemiphaedusa similaris (H. Adams, 1867)}

http://www.taibif.tw/en/catalogue_of_life/page/8800-40ed-d9b1-5696-861a-c399$1104-4 \mathrm{dc} 5$-namecode-316647

Figure $1 \mathrm{~K}$

Clausilia (?) similaris H. Adams, 1867: 446, pl. 38 fig. 10. [1866] (Apr. 1867). Hemiphaedusa similaris, Kuroda 1941: 140.

Type locality. Formosa [Taiwan] (Swinhoe).

Material examined. Lectotype. Formosa, from collection of H. Adams (NHMUK 1878.1.28.10/1), new designation, $17.3 \times 4.8 \mathrm{~mm}$, whorls 10 .

Paralectotypes. Formosa, from collection of H. Adams (NHMUK 1878.1.28.10/2, 1 shell). Formosa, coll. Swinhoe (NHMUK 1866.5.9.3, 3 shells).

Remarks. None of these type series exactly match with the illustration and measurements in Adams (1867). The specimen in the best condition is here designated as the lectotype.

\section{Genus Oospira Blanford, 1872}

Oospira formosensis (H. Adams, 1866)

http://www.taibif.tw/en/catalogue_of_life/page/6230-62a2-52e0-7159-5ddc-51e0$783 \mathrm{~b}-\mathrm{d} 62 \mathrm{f}$-namecode- 402850

Figure 2A

Clausilia (Phaedusa) formosensis H. Adams, 1866: 317, pl. 33 fig. 7.

Oospira (Formosana) formosensis, Nordsieck 1997: 11.

Type locality. Takow, Formosa [northern Qi-Jin, Kaohsiung City] (Swinhoe)

Material examined. Lectotype. Formosa, coll. Swinhoe (NHMUK 1866.5.9.5/1), new designation, $26.1 \times 7.0 \mathrm{~mm}$, whorls 10 .

Paralectotypes. Formosa, coll. Swinhoe (NHMUK 1866.5.9.5/2-3, 2 shells). Formosa, from collection of H. Adams (NHMUK 1878.1.28.245, 1 shell). 


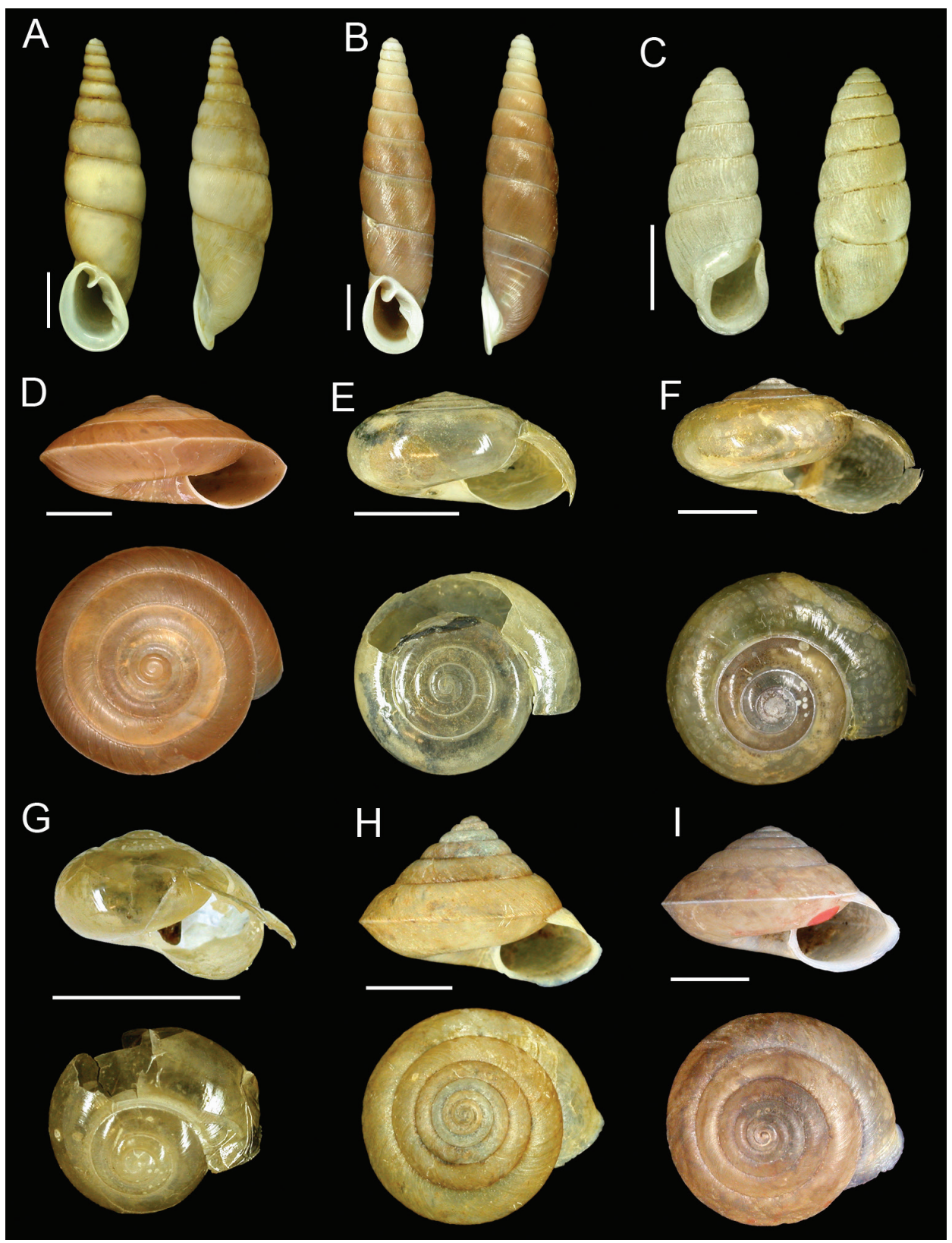

Figure 2. A Oospira formosensis (H. Adams, 1866), lectotype NHMUK 1866.5.9.5/1 B Oospira swinhoei (Pfeiffer, 1866), lectotype NHMUK 20040583/1 C Elma swinhoei (H. Adams, 1866), lectotype NHMUK 1866.5.9.14/1 D Videnoida shermani (Pfeiffer, 1866), lectotype NHMUK 20040584/1 E Petalochlamys formosanus (Schmacker \& Boettger, 1891) syn. Petalochlamys hypograpta Godwin-Austen, 1907, holotype NHMUK 1903.7.1.1713 F Petalochlamys vesta (Pfeiffer, 1866), lectotype NHMUK 20040580 G Ovachlamys fulgens (Gude, 1900) syn. Lamprocystis fulgida Godwin-Austen, 1907, holotype NHMUK 1903.7.1.1714 H Aegista fulvicans (H. Adams, 1866), lectotype NHMUK 1866.5.9.10/1 I Aegista granti (Pfeiffer, 1866), lectotype NHMUK 20040579. Scale bars $=5 \mathrm{~mm}$. 
Remarks. The specimen corresponding well in size with the measurements of Adams (1866) is designated as the lectotype for the stabilization of the name (ICZN 1999: Art. 74). Adams (1866) described the locality as Takow, Formosa. This species has recently been recorded by Hsieh et al. (2013) in the Liu-gui and Mei-nong areas in eastern Kaohsiung City, which were visited by Swinhoe during his collection trip through southern Taiwan. This species was unlikely to have been collected in Takow (coastal areas of Kaohsiung City in 1866). Apparently, Swinhoe or Adams used Takow to represent an area approximating present-day Kaohsiung City. The same situation was also observed for the type locality of Platryhaphe swinhoi and Dioryx swinhoei.

\section{Oospira swinhoei (Pfeiffer, 1866)}

http://www.taibif.tw/en/catalogue_of_life/page/f228-43fd-a0a7-32f2-aaea-1ba6e70c-854d-namecode-402851

Figure 2B

Clausilia swinhoei Pfeiffer, 1866: 830, pl. 46 fig. 11. [1865] (Apr. 1866). Oospira (Formosana) swinhoei, Nordsieck 1997: 11.

Type locality. Formosa [Taiwan] (Swinhoe)

Material examined. Lectotype. Formosa, coll. Swinhoe, from collection of $\mathrm{H}$. Cuming (NHMUK 20040583/1), new designation, $35.0 \times 8.1 \mathrm{~mm}$, whorls 10 .

Paralectotypes. Formosa, coll. Swinhoe, from collection of H. Cuming (NHMUK 20040583/2-3, 2 shells).

Remarks. The original description gives a range of shell dimensions. The largest specimen is designated as the lectotype.

\section{Family STREPTAXIDAE}

Genus Elma H. Adams, 1866

Elma swinhoei (H. Adams, 1866)

http://www.taibif.tw/en/catalogue_of_life/page/45f2-e28e-c620-b0cb-2306-5af5-f5140395-namecode-402881

Figure 2C

Ennea (Elma) swinhoei H. Adams, 1866: 317-318, pl. 33 fig. 8.

Elma swinhoei, Kuroda 1941: 148.

Type locality. Tamsui, Formosa [Danshui, New Taipei City] (Swinhoe)

Material examined. Lectotype. Formosa, coll. Swinhoe (NHMUK 1866.5.9.14/1), new designation, $15.7 \times 6.1 \mathrm{~mm}$, whorls 9 . 
Paralectotypes. Formosa, coll. Swinhoe (NHMUK 1866.5.9.14/2-3, 2 shells). Tamsui, Formosa, coll. Swinhoe, from collection of H. Adams (NHMUK 1878.1.28.30, 3 shells).

Remarks. The largest specimen corresponds well in size with the measurements of Adams (1866). It is here selected as the lectotype for the stabilization of the name (ICZN 1999: Art. 74).

\section{Family TROCHOMORPHIDAE \\ Genus Videnoida Habe, 1955}

Videnoida shermani (Pfeiffer, 1866)

http://www.taibif.tw/en/catalogue_of_life/page/af4c-5a14-6587-4495-c500-e4ba-0b5f8a08-namecode-316729

Figure 2D

Helix shermani Pfeiffer, 1866: 828, pl. 46 fig. 5. [1865] (Apr. 1866).

Videnoida shermani, Chang 1994: 17.

Type locality. Formosa [Taiwan] (Swinhoe).

Material examined. Lectotype. Formosa, coll. Swinhoe, from collection of $\mathrm{H}$. Cuming (NHMUK 20040584/1), new designation, $8.7 \times 19.3 \mathrm{~mm}$, whorls 7 .

Paralectotypes. Formosa, coll. Swinhoe, from collection of H. Cuming (NHMUK 20040584/2-3, 2 shells).

Remarks. The largest specimen mostly similar to the illustration in Pfeiffer (1866) is designated as the lectotype.

\section{Family ARIOPHANTIDAE}

Genus Petalochlamys Godwin-Austen, 1907

Petalochlamys formosanus (Schmacker \& Boettger, 1891)

Syn. Petalochlamys hypograpta Godwin-Austen, 1907

http://www.taibif.tw/en/catalogue_of_life/page/7b11-e296-0f06-7c00-8eef-6282-8085ec60-namecode-316691

Figure 2E

Macrochlamys (Petalochlamys) formosana var. hypograpta Godwin-Austen, 1907: 206, 212-214, pl. 115 figs. 2, 2b, pl. 116 figs. 5, 5b. (Apr. 1907).

Type locality. South Formosa [southern Taiwan] (Hirase)

Material examined. Holotype. Southern Formosa, from collection of Hirase (NHMUK 1903.7.1.1713), designated by monotypy, $11.0 \times 6.3 \mathrm{~mm}$, whorls 5.5 . (Figure 2E). 
Remarks. This name was first recommended by Pilsbry for specimens from Hirase's collection (Hirase 1908). However, Godwin-Austen (1907) received a specimen from Hirase, reported on its reproductive system and assigned it as the type species of the genus Petalochlamys. Hirase (1908: 16, published on 20 Jan. 1908) described his own specimens as a new variety of the same name in Japanese, on the basis of specimens collected from Hotawa; however, he also cited Godwin-Austen's study in a Japanese translation. Therefore, Godwin-Austen's 1907 publication unintentionally took precedence over Hirase's work, thereby claiming the authorship of this name. Being the type species of the genus, the name was thus elevated to the rank of species (ICZN 1999: Art. 61.4).

\section{Petalochlamys vesta (Pfeiffer, 1866)}

http://www.taibif.tw/en/catalogue_of_life/page/206a-098e-58ca-00df-95c8-1038-5142b787-namecode-316694

Figure $2 \mathrm{~F}$

Helix vesta Pfeiffer, 1866: 828, pl. 46 fig. 9. [1865] (Apr. 1866).

Petalochlamys vesta, Matsuda 1924: 49.

Type locality. Formosa [Taiwan] (Swinhoe)

Material examined. Lectotype. Formosa, coll. Swinhoe, from collection of H. Cuming (NHMUK 20040580), new designation, $8.5 \times 16 \mathrm{~mm}$, whorls 5.5.

Remarks. Although only one specimen is found in the NHM, it should be designated as lectotype under ICZN (1999: Rec. 73F).

\section{Genus Ovachlamys Habe, 1946 \\ Ovachlamys fulgens (Gude, 1900)}

Syn. Lamprocystis fulgida Godwin-Austen, 1907 http://www.taibif.tw/en/catalogue_of_life/page/6f48-0a31-58ff-26e8-8637-e924-fbe99a3a-namecode-316684

Figure 2G

Macrochlamys fulgens Gude, 1900: 75, pl. 8 figs. 24-26.

Lamprocystis? fulgida Godwin-Austen, 1907: 214, pl. 115 figs. 3-3f, pl. 116 figs. 6-6a.

Type locality. South Formosa [southern Taiwan] (Hirase)

Material examined. Holotype of Lamprocystis fulgida. South Formosa, from collection of Hirase (NHMUK 1903.7.1.1714), designated by monotypy, $4 \times 7.3 \mathrm{~mm}$, whorls 4.5.

Remarks. Godwin-Austen (1907) described the specimen as being $9.75 \mathrm{~mm}$ in shell width. By comparing his measurement with mine, I concluded that his was probably an inadvertent error. 


\section{Family BRADYBAENIDAE \\ Genus Aegista Albers, 1850}

\section{Aegista fulvicans (H. Adams, 1866)}

http://www.taibif.tw/en/catalogue_of_life/page/7c64-c58c-12eb-ac55-a7cd-a0965667-5d70-namecode-404845

Figure $2 \mathrm{H}$

Helix (Plectotropis) fulvicans H. Adams, 1866: 316, pl. 33 fig. 2. Aegista (Plectotropis) fulvicans, Kuroda 1941: 147.

Type locality. Tamsui, Formosa [Danshui, New Taipei City] (Swinhoe)

Material examined. Lectotype. Formosa, coll. Swinhoe (NHMUK 1866.5.9.10/1), new designation, $9.9 \times 14 \mathrm{~mm}$, whorls 7 .

Paralectotypes. Formosa, coll. Swinhoe (NHMUK 1866.5.9.10/2-3, 2 shells). Formosa, from collection of H. Adams (NHMUK 1878.1.23.204, 2 shells).

Remarks. Adams (1866) described the locality as Tamsui, Formosa, but the original label has only "Formosa". The largest specimen mostly similar to the illustration in Adams (1866) is designated as the lectotype.

\section{Aegista granti (Pfeiffer, 1866)}

http://www.taibif.tw/en/catalogue_of_life/page/7c64-c58c-12eb-ac55-a7cd-a0965667-5d70-namecode- 404845

Figure 2I

Helix granti Pfeiffer, 1866: 828-829, pl. 46 fig. 10. [1865] (Apr. 1866).

Aegista (Plectotropis) granti, Kuroda 1941: 147.

Type locality. Formosa [Taiwan] (Swinhoe)

Material examined. Lectotype. Formosa, coll. Swinhoe, from collection of H. Cuming (NHMUK 20040579), new designation, $8.9 \times 14.4 \mathrm{~mm}$, whorls 6.5.

Remarks. Although only one specimen is found in the NHM, it should be designated as lectotype under ICZN (1999 Rec. 73F).

\section{Genus Pseudobuliminus Gredler, 1887}

\section{Pseudobuliminus incertus (Pfeiffer, 1866)}

http://www.taibif.tw/en/catalogue_of_life/page/ded5-2c76-8885-2134-814e-8b5e-d842c8e9-namecode-404771

Figure $3 \mathrm{~A}$

Bulimus incertus Pfeiffer, 1866: 830, pl. 46 fig. 1. [1865] (Apr. 1866). Pseudobuliminus incertus, Schmacker and Boettger 1891: 163. 
Type locality. Formosa [Taiwan] (Swinhoe)

Material examined. Lectotype. Formosa, coll. Swinhoe, from collection of H. Cuming (NHMUK 20040582/1), new designation, ca. $10 \times 4.5 \mathrm{~mm}$, whorls 9.5 (peristome damaged).

Paralectotypes. Formosa, coll. Swinhoe, from collection of H. Cuming (NHMUK 20040582/2-4, 3 shells).

Remarks. The largest specimen corresponds well in size with the measurements of Pfeiffer (1866). It is here selected as the lectotype for the stabilization of the name (ICZN 1999: Art. 74).

\section{Genus Acusta Albers, 1860}

\section{Acusta assimilis (H. Adams, 1866)}

http://www.taibif.tw/en/catalogue_of_life/page/f063-8247-3258-a7f9-1230-23a1-7f12e537-namecode-316552

Figure 3B

Nanina (Acusta) assimilis H. Adams, 1866: 316, pl. 33 fig. 1. Acusta assimilis, Chang 1984: 18.

Type locality. Takow, Formosa [northern Qi-Jin, Kaohsiung City] (Swinhoe)

Material examined. Lectotype. Formosa, coll. Swinhoe (NHMUK 1866.5.9.11/1), new designation, $13.7 \times 19.4 \mathrm{~mm}$, whorls 5.75 .

Paralectotypes. Formosa, coll. Swinhoe (NHMUK 1866.5.9.11/2-3, 2 shells).

Remarks. Adams (1866) described the locality as Takow, Formosa, but the original label has only "Formosa". The lot NHMUK 1866.5.9.11 was first registered and labelled as "Nanina propinqua", then later published as $N$. assimilis. None of these shells exactly match with the measurements of Adams (1866). The specimen in the best condition is designated as the lectotype for the stabilization of the name (ICZN 1999: Art. 74).

\section{Acusta toyenmongaiensis Rolle, 1911}

Acusta toyenmongaiensis Rolle, 1911: 32.

Type locality. Toyenmongai, Formosa [Dong-yuan-men-jie, Tainan = central area of modern-day Tainan City] (Rolle?)

Material examined. Lectotype. Toyenmongai, Formosa (SMF 7405), designated by Zilch (1968, pl. 7, fig. 27).

Paralectotypes. Formosa (NHMUK 1912.8.16.131-133, 3 shells, "original specimen”) , 11.3-12.3 × 13.3-14.2 mm, whorls 5.25-5.5. Also in SMF. 


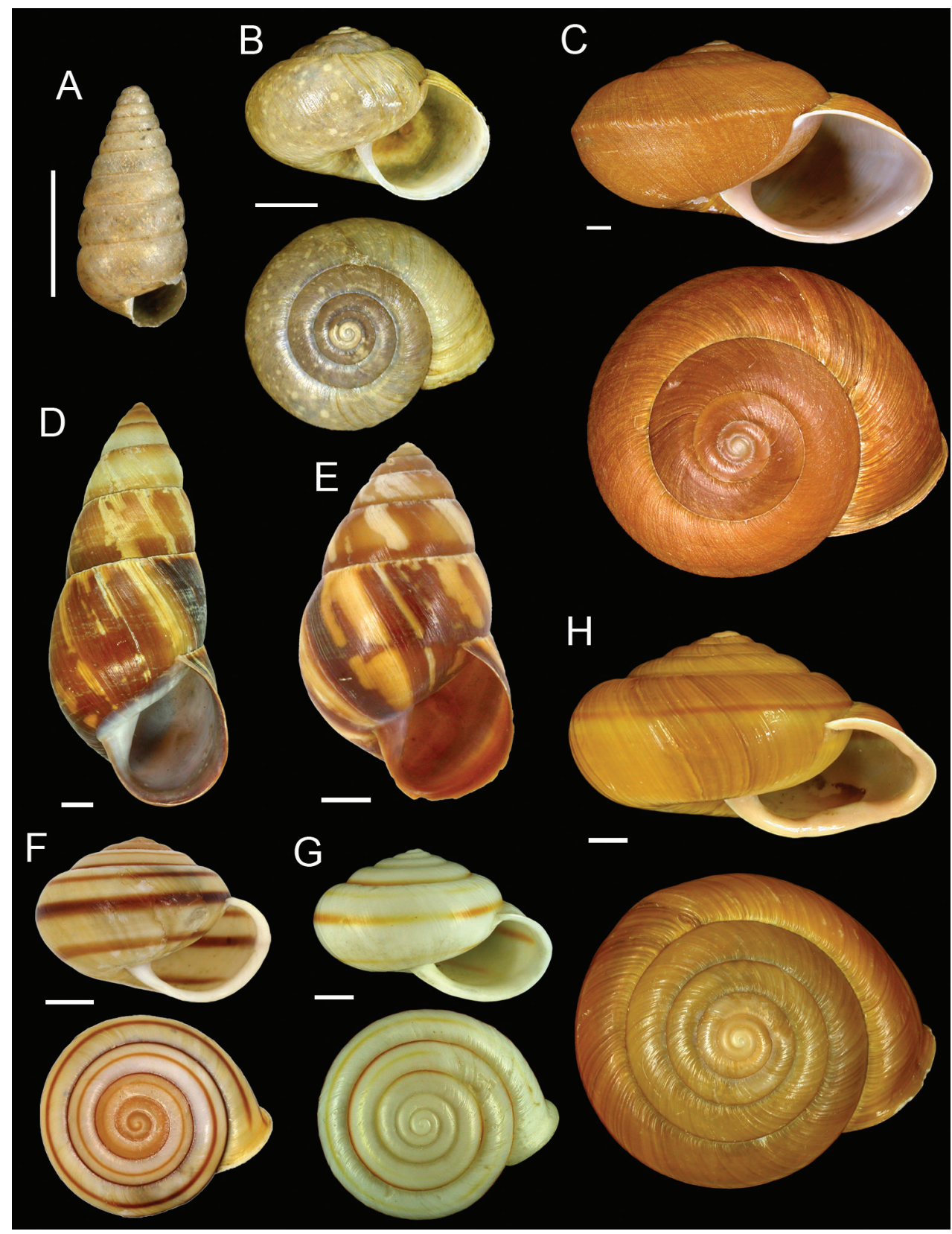

Figure 3. A Pseudobuliminus incertus (Pfeiffer, 1866), lectotype NHMUK 20040582/1 B Acusta assimilis (H. Adams, 1866), lectotype NHMUK 1866.5.9.11/1 C Nesiohelix swinhoei (Pfeiffer, 1866), lectotype NHMUK 20040585/1 D Dolicheulota formosensis (H. Adams, 1866), lectotype NHMUK 1866.5.9.1/1 E Dolicheulota swinhoei (Pfeiffer, 1866), lectotype NHMUK 20040586/1 F Satsuma bacca (Pfeiffer, 1866), lectotype NHMUK 20040577/1 G Satsuma bacca (Pfeiffer, 1866) syn. Eulota warburgi Gude, 1907, holotype NHMUK 1922.8.29.66 H Satsuma bairdi (H. Adams, 1866), lectotype NHMUK 20040587/1. Scale bars $=5 \mathrm{~mm}$. 


\section{Genus Nesiohelix Kuroda \& Emura, 1943}

\section{Nesiohelix swinhoei (Pfeiffer, 1866)}

http://www.taibif.tw/en/catalogue_of_life/page/6229-bc2d-cbaa-81c2-e0f7-c761-093609a5-namecode-316578

Figure 3C

Helix swinhoei Pfeiffer, 1866: 829, pl. 46 fig. 6. [1865] (Apr. 1866).

Nesiohelix swinhoei, Kuroda 1941: 148.

Type locality. Formosa [Taiwan] (Swinhoe).

Material examined. Lectotype. Formosa, coll. Swinhoe, from collection of H. Cuming (NHMUK 20040585/1, large form), new designation, $42.7 \times 75.3 \mathrm{~mm}$, whorls 5.5.

Paralectotypes. Formosa, coll. Swinhoe, from collection of H. Cuming (NHMUK $20040585 / 2$, 1 shell, large form, $50.9 \times 68.1 \mathrm{~mm}$, whorls 5.25; NHMUK 20040585/34, 2 shells, small form, 32.4-32.5 × 50.8-54.5 mm, whorls 4.75-5.0).

Remarks. The shell sizes of these four specimens do not agree with Pfeiffer's original measurements of $27-28 \times 52-58 \mathrm{~mm}$ for the typical form and $25 \times 46 \mathrm{~mm}$ for the minor form. I consider Pfeiffer's measurements to be incorrect. The largest specimen is designated as the lectotype for the stabilization of the name (ICZN 1999: Art. 74).

\section{Genus Dolicheulota Pilsbry, 1901}

\section{Dolicheulota formosensis (H. Adams, 1866)}

http://www.taibif.tw/en/catalogue_of_life/page/d4d5-9c75-7cde-9aa3-c80d-6ae0-ec2beda7-namecode-316574

Figure 3D

Bulimus (Amphidromus) formosensis H. Adams, 1866: 317, pl. 33 fig. 5.

Dolicheulota formosensis, Pilsbry and Hirase 1906: 735.

Type locality. Tamsui Mountains, Formosa [Danshui, New Taipei City] (Swinhoe).

Material examined. Lectotype. Formosa, coll. Swinhoe (NHMUK 1866.5.9.1/1), new designation, $55.4 \times 24 \mathrm{~mm}$, whorls 8 .

Paralectotypes. Formosa, coll. Swinhoe (NHMUK 1866.5.9.1/2-3, 2 shells).

Remarks. Adams (1866) described the locality as Tamsui Mountains, Formosa, but the original label has only "Formosa". The largest specimen corresponding well in size with the measurements of $\mathrm{H}$. Adams (1866) is designated as the lectotype for the stabilization of the name (ICZN 1999: Art. 74). 


\section{Dolicheulota swinhoei (Pfeiffer, 1866)}

http://www.taibif.tw/en/catalogue_of_life/page/291f-4ce7-4fad-078f-d5bb-38ba7785-3f53-namecode-316575

Figure $3 \mathrm{E}$

Bulimus swinhoei Pfeiffer, 1866: 830, pl. 46 figs. 2, 2a. [1865] (Apr. 1866).

Dolicheulota swinhoei Pilsbry \& Hirase, 1906: 735.

Type locality. Formosa [Taiwan] (Swinhoe)

Material examined. Lectotype. Formosa, coll. Swinhoe, from collection of H. Cuming (NHMUK 20040586/1), new designation, $37.1 \times 21.4 \mathrm{~mm}$, whorls 7 .

Paralectotypes. Formosa, coll. Swinhoe, from collection of H. Cuming (NHMUK 20040586/2-3, 2 shells, one bleached and the other immature).

Remarks. The specimen in the best condition is designated as the lectotype for the stabilization of the name (ICZN 1999: Art. 74).

\section{Family CAMAENIDAE}

Genus Satsuma A. Adams, 1868

Satsuma albida (H. Adams, 1870)

http://www.taibif.tw/en/catalogue_of_life/page/80bb-3054-2d71-db66-01fb-62887ba3-1741-namecode-402896

Helix (Satsuma) albida H. Adams, 1870: 378, pl. 27 fig. 9.

Satsuma albida, Minato, 1976: 84.

Type locality. Taiwan, Formosa [Taiwan Fu = Tainan City and northern Kaohsiung City] (Swinhoe).

Material examined. Lectotype. Takow, Formosa, from collection of H. Adams (NHMUK 1878.1.28.229), designated and photographed by Wu et al. (2008), $15 \times$ $14 \mathrm{~mm}$, whorls 5.8 .

Remarks. Adams (1870) described the locality as Taiwan, Formosa, but it is " Takow, Formosa" on the label. See Wu et al. (2008) for a discussion of the type locality.

\section{Satsuma bacca (Pfeiffer, 1866)}

http://www.taibif.tw/en/catalogue_of_life/page/3b47-78d4-0970-b4b4-ae3c-e171-67c8d0cc-namecode-316610

Figure $3 \mathrm{~F}$

Helix bacca Pfeiffer, 1866: 829, pl. 46 fig. 8. [1865] (Apr. 1866).

Satsuma bacca, Richardson 1985: 268. 
Type locality. Formosa [Taiwan] (Swinhoe).

Material examined. Lectotype of Helix bacca. Formosa, coll. Swinhoe, from collection of H. Cuming (NHMUK 20040577/1), new designation, $16.6 \times 24.5 \mathrm{~mm}$, whorls 5.5. (Figure 3F)

Paralectotype of Helix bacca. Formosa, coll. Swinhoe, from collection of H. Cuming (NHMUK 20040577/2, 1 shell, immature).

Remarks. This species was usually considered as a member of Pancala Kuroda \& Habe, 1949. Hwang (2011) transferred it to the current genus because of genital and conchological similarities. Besides, Pancala is preoccupied by a dipteran genus (Enderlein 1936). The only mature specimen is designated as lectotype.

\section{Satsuma bacca (Pfeiffer, 1866)}

\section{Syn. Eulota (Euhadra) warburgi Gude, 1907}

Figure 3G

Eulota (Euhadra) warburgi Gude, 1907: 164-165, figs. 1, 2.

Type locality. Dunes at Long-Krau, South Formosa [coastal area of Northwest Hengchung Peninsula] (Warburg)

Material examined. Holotype of Eulota (Euhadra) warburgi. Dunes at Long-Krau, Southern Formosa, coll. Warburg, Feb. 1888, from collection of Naturhistorisches Museum, Hamburg (NHMUK 1922.8.29.66), original designation, $19.2 \times 30.5 \mathrm{~mm}$, whorls 5.75. (Figure 3G)

\section{Satsuma bairdi (H. Adams, 1866)}

http://www.taibif.tw/en/catalogue_of_life/page/6293-3ac5-ce65-683e-ef8c-6101-7142a9e1-namecode-402916

Figure $3 \mathrm{H}$

Helix (Camaena) bairdi H. Adams, 1866: 316, pl. 33 fig. 3.

Satsuma bairdi, Richardson 1985: 268.

Type locality. Tamsui, Formosa [Danshui, New Taipei City] (Swinhoe)

Material examined. Lectotype. Formosa, coll. Swinhoe, from collection of $\mathrm{H}$. Cuming (NHMUK 20040587/1), new designation, $22.7 \times 40.0 \mathrm{~mm}$, whorls 6.25.

Paralectotypes. Formosa, coll. Swinhoe, from collection of H. Cuming (NHMUK 20040587/2-3, 2 shells).

Remarks. Adams (1866) described the locality as Tamsui, Formosa, but the original label has only "Formosa". None of these shells exactly match with the measurements of Adams (1866). The specimen in the best condition is designated as the lectotype for the stabilization of the name (ICZN 1999: Art. 74). 


\section{Satsuma formosensis (Pfeiffer, 1866)}

http://www.taibif.tw/en/catalogue_of_life/page/8f82-28a2-5e55-911c-d11c-a5ce1537-af29-namecode-402919

Figure 4A

Helix formosensis Pfeiffer, 1866: 829, pl. 46 fig. 7. [1865] (Apr. 1866).

Satsuma formosensis, Richardson 1985: 270.

Type locality. Formosa [Taiwan] (Swinhoe).

Material examined. Lectotype. Formosa, coll. Swinhoe, from collection of $\mathrm{H}$. Cuming (NHMUK 20040578), new designation, $17 \times 26 \mathrm{~mm}$, whorls 6 .

Remarks. Pfeiffer (1866) mentioned that the shell height is $12-13 \mathrm{~mm}$, but only one specimen is found in the NHM. More than one specimen was probably examined by Pfeiffer. Therefore, this is designated as a lectotype instead of a holotype.

\section{Satsuma mellea (Pfeiffer, 1866)}

http://www.taibif.tw/en/catalogue_of_life/page/8cbf-f9d6-70dd-b1d2-abbf-2f09-2c6e8166-namecode-402922

Figure 4B

Helix mellea Pfeiffer, 1866: 829-830, pl. 46 fig. 4. [1865] (Apr. 1866).

Satsuma melleum (sic.), Lai 1990: 50.

Type locality. Formosa [Taiwan] (Swinhoe)

Material examined. Lectotype. Formosa, coll. Swinhoe, from collection of $\mathrm{H}$. Cuming (NHMUK 20040576/1), new designation, $11 \times 23.2 \mathrm{~mm}$, whorls 5 .

Paralectotypes. Formosa, coll. Swinhoe, from collection of H. Cuming (NHMUK 20040576/2-3, 2 shells).

Remarks. The largest specimen mostly similar to the illustration in Pfeiffer (1866) is designated as the lectotype.

\section{Satsuma sphaeroconus (Pfeiffer, 1866)}

http://www.taibif.tw/en/catalogue_of_life/page/676b-ddd0-aa05-0ce7-2977-e3c78bb4-25e3-namecode-402928

Figure 4D

Bulimus sphaeroconus Pfeiffer, 1866: 830, pl. 46 fig. 3. [1865] (Apr. 1866).

Satsuma (Coniglobus) sphaeroconus, Kuroda and Habe 1949: 59.

Type locality. Formosa [Taiwan] (Swinhoe)

Material examined. Lectotype. Formosa, coll. Swinhoe, from collection of $\mathrm{H}$. Cuming (NHMUK 20040575/1), new designation, $23.1 \times 18.5$ mm, whorls 6 . 


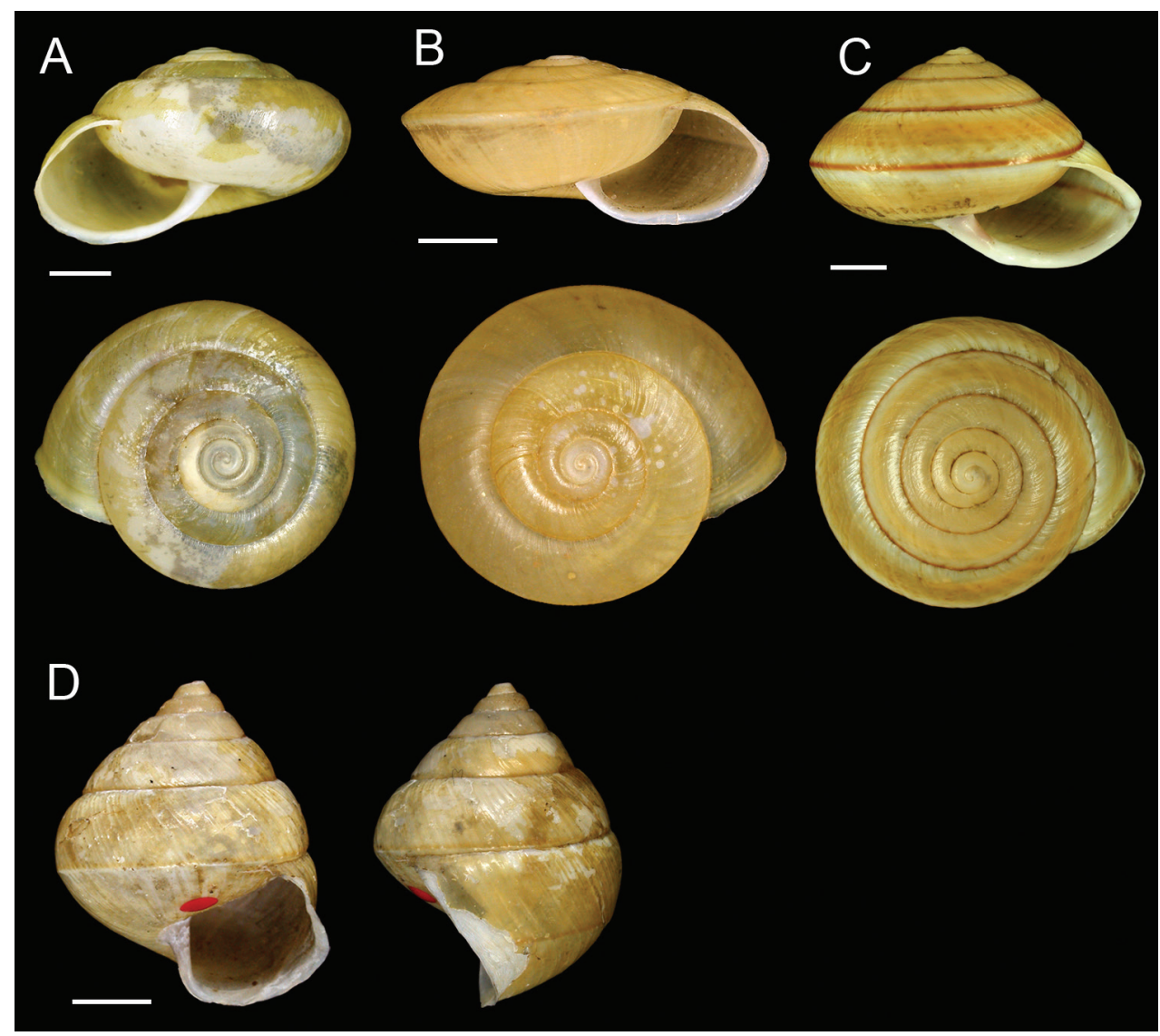

Figure 4. A Satsuma formosensis (Pfeiffer, 1866), lectotype NHMUK 20040578 B Satsuma mellea (Pfeiffer, 1866), lectotype NHMUK 20040576/1 C Satsuma succincta (H. Adams, 1866), lectotype NHMUK 1866.5.9.9/1 D Satsuma sphaeroconus (Pfeiffer, 1866), lectotype NHMUK 20040575/1. Scale bars $=5 \mathrm{~mm}$.

Paralectotype. Formosa, coll. Swinhoe, from collection of H. Cuming (NHMUK 20040575/2, 1 shell, immature).

Remarks. The only mature shell with a red spot is designated as the lectotype.

\section{Satsuma succincta (H. Adams, 1866)}

http:/www.taibif.tw/en/catalogue_of_life/page/4aa0-b629-2eb1-14c9-054a-7754-f168a2e8-namecode-402929

Figure 4C

Helix (Camaena) succincta H. Adams, 1866: 316-317, pl. 33 figs. 4, 4a. Satsuma succincta, Richardson 1985: 273.

Type locality. Takow, Formosa [northern Qi-Jin, Kaohsiung City] (Swinhoe). 
Material examined. Lectotype. Takow Mountain, Formosa, coll. Swinhoe (NHMUK 1866.5.9.9/1), new designation, $22.8 \times 31.2 \mathrm{~mm}$, whorls 6.5.

Paralectotypes. Takow Mountain, Formosa, coll. Swinhoe (NHMUK 1866.5.9.9/26, 5 shells; NHMUK 1866.5.9.9/7, 1 shell, non succincta, immature shell of Aegista lautsi branchylasis (Schmacker \& Boettger, 1891)).

Remarks. One of the specimens is labelled "Takow mountains" on base of shell. It is here selected as the lectotype for the stabilization of the name (ICZN 1999: Art. 74).

\section{Genus Yakuchloritis Habe, 1955}

\section{Yakuchloritis hungerfordianus (Moellendorff, 1884)}

http:/www.taibif.tw/en/catalogue_of_life/page/ac86-40bf-dd43-3659-1e45-9174-49a88ff4-namecode-316613

Helix hungerfordiana Moellendorff, 1884: 336-337, pl. 7 fig. 7. Yakuchloritis hungerfordianus, Chang 1990: 36.

Type locality. insulae Hongkong [Hongkong Islands] (Moellendorff)

Material examined. Lectotype. Hong Kong (SMF 45429), designated by Zilch (1966b, fig. 42).

Paralectotypes. Hong Kong and Guangdung, China (SMF, 11 shells) (Zilch 1966b).

Possible paralectotypes. Keelung, Formosa, coll. Hungerford (NHMUK 1891.3.17.56, 2 shells), $9.6 \times 18.1 \mathrm{~mm}$, whorls 5.5; $9.7 \times 16.5$, whorls 5.5.

Remarks. This species was named by Nevill, in a letter to Hungerford, on the basis of the samples that Hungerford collected from Formosa; however, the species was not published until 1884 by Moellendorff. Having examined Moellendorff's collection from Hong Kong and Guangdung (Moellendorff 1884), I cannot find evidence of whether the lot in the NHM was actually seen by Moellendorff. Since he listed Formosa as one of the localities, I consider the specimens in the NHM to be possible paralectotypes.

\section{Genus Moellendorffia Ancey, 1887 Moellendorffia hiraseana Pilsbry, 1905}

\section{Syn. Stegodera (Tribelix) belleri Rolle, 1911}

http://www.taibif.tw/en/catalogue_of_life/page/1c56-7520-15b7-106a-322e-2f3c-77bb032c-namecode-316609

Moellendorffia (Tribelix) hiraseana Pilsbry, 1905: 66-67, pl. 2 fig. 4-6. Stegodera (Tribelix) helleri Rolle, 1911: 31-32.

Type locality. Toyenmongai auf Formosa [Dong-yuan-men-jie, Tainan = central area of modern-day Tainan City] (Rolle?) 
Material examined. Lectotype of Stegodera helleri. Toyenmongai, Formosa, coll. Rolle, 1910 (SMF 7404), designated as holotype by Zilch (1966a, fig. 57), see remarks below.

Paralectotypes of Stegodera helleri. (SMF, 4 shells) (Zilch 1966a).

Possible paralectotypes of Stegodera helleri. Toyenmongai, Formosa, coll. Rolle, "1/2/11", from collection of V.W. MacAndrew, no. 1563 (NHMUK 20040594, 4 shells), 6.4-6.9 × 15.9-17.4mm, whorls 4.75.

Remarks. No holotype was originally fixed by Rolle (1911). Zilch (1966a) considered a specimen in SMF as the holotype, which here is accepted as a subsequent lectotype designation, and thus all other specimens from Rolle's original lot receive the status of paralectotypes under Art. 74.6, ICZN (1999).

\section{Acknowledgments}

I gratefully acknowledge the assistance of all staff members in the Mollusca Research Group, Department of Zoology (NHM), and the librarians of the Museum. Special appreciation is directed to Fred Naggs, Jonathan Ablett and Manuel Malaquias. I also thank Paul Callomon (ANSP) for his help with locating types in the ANSP. I am grateful to R. Janssen, E. Neubert and H. Nordsieck (SMF) for their kindly having permitted and helped my study of type material. Lastly, I am indebted to The Biodiversity Heritage Library for providing access to rare literatures consulted for this work (www. biodiversitylibrary.org). The author wishes to express appreciation to Cheryl Rutledge for her editorial assistance. This study is partly granted by NSC-98-2621-B-390-001.

\section{References}

Adams H (1866) Descriptions of fifteen new species land and freshwater shells from Formosa, collected by Robert Swinhoe, Esq., Consul at Taiwan in that island. Proceedings of the Zoological Society of London 1866: 316-319. http://www.biodiversitylibrary.org/ item/90954\#page/402/mode/1up

Adams H (1867) Description of six new species of shells, and note on Opithostoma de-Crespignii. Proceedings of the Zoological Society of London 1866: 445-447. http://www.biodiversitylibrary.org/item/90954\#page/543/mode/1 up

Adams H (1870) Descriptions of ten new species of land and freshwater shells collected by Robert Swinhoe, Esq., in China and Formosa. Proceedings of the Zoological Society of London 1870: 377-380. http:/www.biodiversitylibrary.org/item/90543\#page/455/mode/1 up

Adams H (1872) Descriptions of fourteen new species of land and marine shells. Proceedings of the Zoological Society of London 1872: 12-15. http://www.biodiversitylibrary.org/ item/90880\#page/40/mode/1up

Baker HB (1963) Type land snails in the Academy of Natural Sciences of Philadelphia part II. Land Pulmonata, exclusive of North America north of Mexico. Proceedings of the Academy of Natural Sciences of Philadelphia 115: 191-259. 
Baker HB (1964) Type land snails in the Academy of Natural Sciences of Philadelphia Part III. Limnophile and Thalassophile Pulmonata Part IV. land and fresh-water Prosobranchia. Proceedings of the Academy of Natural Sciences of Philadelphia 116: 149-193.

Bouchet P, Rocroi J-P (2005) Classification and Nomenclator of Gastropod Families. Malacologia 47: 1-397. https://archive.org/download/malacologia47122005inst/malacologia47122005inst.pdf

Chang KM (1984) Catalogue of the land snail of Taiwan. Pei-Yo 9: 2-19.

Chang KM (1990) Systematics of Trichochloritis hungerfordianus from Taiwan (Pulmonata: Camaenidae). Bulletin of Malacology 15: 35-41.

Chang KM (1994) Anatomy of Aegista (Plectotropis) lautsi (Schmacker \& Boettger) from Taiwan and its systematics (Pulmonata: Bradybaenidae). Bulletin of Malacology 18: 13-20.

Duncan M (1937) On the dates of publication of the Society's 'Proceedings,' 1859-1926. With an appendix containing the dates of publication of 'Proceedings,' $1830-1858$, compiled by the late F.H. Waterhouse, and the 'Transactions,' $1833-1868$, by the late Henry Peavot, originally published in P.Z.S. 1893, 1913. Proceedings of the Zoological Society of London, Series A 107: 71-84.

Enderlein G (1936) Klassifikation der Rutiliinen. Veröffentlichungen aus dem Deutschen Kolonial-und Übersee-Museum in Bremen 1: 397-446.

Fraser L (1865) On the mollusks of Formosa. Proceedings of the Zoological Society of London 1865: 196-197. http://www.biodiversitylibrary.org/item/90412\#page/236/mode/1up

Fraser L (1866) On Formosan mollusks. Proceedings of the Zoological Society of London 1866: 146. http://www.biodiversitylibrary.org/item/90954\#page/196/mode/1 up

Godwin-Austen HH (1907) Land and Freshwater Mollusca of India, Including South Arabia, Baluchistan, Afghanistan, Kashmir, Nepal, Burmah, Pegu, Tenasserim, Malay Peninsula, Ceylon, and Other Islands of the Indian Ocean. Vol. 2, part 10. Taylor and Francis, London, 147-238.

Gray JE (1868) Notes on the specimens of Calyptraeidae in Mr. Cuming's collection. Proceedings of the Zoological Society of London 1867: 726-748. http://www.biodiversitylibrary. org/item/93424\#page/748/mode/1 up

Gude GK (1900) Further notes on helicoid land shells from Japan, the Loo-Choo, and Bonin Islands, with descriptions of seven new species. Proceedings of the Malacological Society 4: 70-80. http://www.biodiversitylibrary.org/item/53747\#page/106/mode/1up

Gude GK (1907) Description of a new species of Eulota from Formosa. Annals and Magazine of Natural History, Series 7 19: 164-165. http://www.biodiversitylibrary.org/ item/78260\#page/178/mode/1up

Habe T, Inaba A (1996) Catalogue of the Shellfish Type Specimens Described by the Late Dr. Tokubei Kuroda in the Possession of Nishinomiya City. Nishinomiya City, Nishinomiya, Japan, 152 pp.

Hebert PDN, Cywinska A, Ball SL, deWaard JR (2003) Biological identifications through DNA barcodes. Proceedings of the Royal Society of London B 270: 313-322. doi: $10.1098 / \mathrm{rspb} .2002 .2218$

Hsieh BC, Wu SP, Tsai CL (2013) Land Snails of Taiwan, 3rd ed. Forestry Bureau, Council of Agriculture, Executive Yuan, Taiwan, Taipei, 381 pp. 
Hwang CC (2005) A review of research on Taiwanese land snails. Notes and Newsletter of Wildlifers 9: 15-20.

Hwang CC (2011) Anatomy and taxonomy of Satsuma succincta (Adams, 1866) and Satsuma batanica pancala (Schmacker \& Boettger, 1891) (Gastropoda: Camaenidae) from southern Taiwan. Bulletin of Malacology 35: 1-11. http://www.airitilibrary.com/Publication/alDet ailedMesh?DocID=02506378-201112-201203120006-201203120006-2-12

Hwang CC, Wu SP, Ohara K, Otani Y, Otani JU (2008) Further land snail types collected from Taiwan and deposited in the Nishinomiya Shell Museum. Venus 67: 1-8.

ICZN (1999) International Code of Zoological Nomenclature. 4th Edition. The International Trust for Zoological Nomenclature, London. http://www.nhm.ac.uk/hosted-sites/iczn/code/ Kobelt W, Moellendorff OF von (1897) Catalog der gegenwärtig lebend bekannten Pneumonopomen. Nachrichtsblatt der Deutschen Malakozoologischen Gesellschaft 29: 73-88, 105-120, 137-152.

Kuroda T (1941) A catalogue of molluscan shells from Taiwan (Formosa), with description of new species. Memoirs of the Faculty of Science and Agriculture Taihoku Imperial University 12: 65-216.

Kuroda T, Habe T (1949) Helicacea. Sanmeisha, Tokyo, v+129 pp.

Lai KY (1990) World of Landsnails. Taiwan Museum, Taipei, 98 pp.

Matsuda E (1924) Catalogue of Mollusks of Taiwan (II) land and freshwater snail. Transactions of the Natural History Society of Formosa 14: 41-59.

Minato H (1976) Genital studies of the Japanese land snails - VII. The genitalia of Satsuma amanoi Kuroda, 1960 and S. tanegashimae (Pilsbry, 1901). Venus 35: 83-86. http://ci.nii. ac.jp/naid/110004763974

Moellendorff OF von (1884) Materialien zur Fauna von China. Jahrbuch der Deutschen Malakozoologischen Gesellschaft 11: 307-390. http://www.biodiversitylibrary.org/ item/55039\#page/321/mode/1 up

Nevill G (1881) New or little-known Mollusca of the Indo-Malay Fauna. Journal of the Asiatic Society of Bengal, Part II Physical Science 50: 125-167. http://www.biodiversitylibrary. org/item/110180\#page/167/mode/1up

Nordsieck H (1997) Annotated check-list of the Taiwanese Phaedusinae (Gastropoda: Stylommatophora: Clausiliidae). Mitteilungen der Deutschen Malakozoologischen Gesellschaft 60: 11-19.

Ohara K, Otani Y (2002) Catalogue of the Dr. Tokubei Kuroda shell collection deposited in the Nishinomiya Shell Museum. Part 1 Non-marine Gastropoda. Bulletin of the Nishinomiya Shell Museum 1: 1-139.

Pfeiffer L (1866) Descriptions of thirteen new species of land-shells from Formosa, in the collection of the late Hugh Cuming, collected by Mr. Robert Swinhoe, Vice-Consul of that island. Proceedings of the Zoological Society of London 1865: 828-831. http://www. biodiversitylibrary.org/item/90412\#page/944/mode/1 up

Pilsbry HA (1905) Notes on Moellendorffia and Stegodera. Nautilus 19: 63-67. http://www. biodiversitylibrary.org/item/17845\#page/81/mode/1up 
Pilsbry HA, Hirase Y (1905-1906) Catalogue of the land and fresh-water Mollusca of Taiwan (Formosa). Proceedings of the Academy of Natural Sciences of Philadelphia 57: 720-752. http://www.biodiversitylibrary.org/item/30015\#page/808/mode/1up

Pilsbry HA, Hirase Y (1909) New land mollusca of the Japanese empire. Proceedings of the Academy of Natural Sciences of Philadelphia 60: 586-599. http://www.biodiversitylibrary.org/item/79152\#page/594/mode/1 up

Richardson L (1985) Camaenidae: catalog of species. Tryonia 12: 1-479.

Rolle H (1911) Diagnosen neuer Arten. Nachrichtsblatt der Deutschen Malakozoologischen Gesellschaft 43: 30-32. http://www.biodiversitylibrary.org/item/52191\#page/44/ mode/1up

Schmacker B, Boettger O (1891) Neue Materialien zur Charakteristik und geographischen Verbreitung chinesischer und japanischer Binnenmollusken II. Nachrichtsblatt der Deutschen Malakozoologischen Gesellschaft 23: 145-194. http://www.biodiversitylibrary.org/ item/53278\#page/793/mode/1 up

Sowerby GB (1878) Monograph of the genus Pupinidae. In: Reeve LA (Ed) Conchologia Iconica, Vol 20. L. Reeve \& Co., London, 10 pls. http://www.biodiversitylibrary.org/ item/34126\#page/321/mode/1 up

Swinhoe R (1864) Notes on the Island of Formosa. Journal of the Royal Geographical Society of London 34: 6-18. doi: 10.2307/1798463

Swinhoe R (1865) Letters from Mr. R. Swinhoe. Proceedings of the Zoological Society of London 1864: 378-383. http:/www.biodiversitylibrary.org/item/90417\#page/462/mode/1 up

Vaught KC (1989) A Classification of the Living Mollusca. American Malacologists, Melbourne, Florida, 195 pp.

Wu SP, Hwang CC, Lin YS (2008) Systematic revision of the arboreal snail Satsuma albida species complex (Mollusca: Camaenidae) with descriptions of fourteen new species from Taiwan. Zoological Journal of the Linnean Society 154: 437-493. doi:10.1111/j.10963642.2008.00415.x

Yen TC (1939) Die chinesischen land-und Süßwasser-Gastropoden des Natur-Museums Senkkenberg. Abhandlungen der Senckenbergischen Naturforschenden Gesellschaft 444: 1-235.

Zilch A (1953) Die Typen und Typoide des Natur-Museums Senckenberg, 9: Mollusca, Cyclophoridae, Diplommatininae. Archiv für Molluskenkunde 82: 1-47.

Zilch A (1957) Die Typen und Typoide des Natur-Museums Senckenberg, 20: Mollusca, Cyclophoridae, Alycaeinae. Archiv für Molluskenkunde 86: 141-150.

Zilch A (1966a) Die Typen und Typoide des Natur-Museums Senckenberg, 35: Mollusca, Camaenidae (4). Archiv für Molluskenkunde 95: 197-223.

Zilch A (1966b) Die Typen und Typoide des Natur-Museums Senckenberg, 35: Mollusca, Camaenidae (5). Archiv für Molluskenkunde 95: 293-319.

Zilch A (1968) Die Typen und Typoide des Natur-Museums Senckenberg, 41: Mollusca, Bradybaenidae, Bradybaeninae. Archiv für Molluskenkunde 98: 155-212. 